\title{
JAMINAN KEBENDAAN DALAM PROSES PERJANJIAN KREDIT PERBANKAN \\ (Tinjauan Yuridis Terhadap Jaminan Benda Bergerak Tidak Berwujud)
}

\author{
GENTUR CAHYO SETIONO \\ Fakultas Hukum Universitas Kadiri \\ Jl. Selomangleng No. 1 Kediri \\ Email : gentur@unik-kediri.ac.id
}

\begin{abstract}
Abstrak
Lembaga Perbankan merupakan salah satu unsur penting dalam berjalannya roda perekonomian di suatu negara, salah satu bidang usaha perbankan tersebut adalah jenis usaha kredit perbankan. Dalam proses perjanjian kredit dalam praktek selalu diikuti dengan perjanjian jaminan dengan maksud sebagai proteksi bagi bank bahwa debitur akan melaksanakan prestasinya sesuai perjanjian. Perjanjian jaminan merupakan perjanjian tambahan yang keberadaannya tergantung dari perjanjian pokok yaitu perjanjian kredit. Dalam praktek perjanjian kredit dan jaminan perbankan, piutang dapat dijadikan sebagai obyek jaminan, lembaga jaminan yang mengatur adalah lembaga jaminan gadai dan jaminan fidusia. Obyek jaminan gadai dan fidusia adalah meliputi benda bergerak berwujud dan benda bergerak tidak berwujud yang dapat berupa piutang.
\end{abstract}

Kata Kunci : kredit perbankan, jaminan kebendaan, benda bergerak tidak berwujud 


\section{LATAR BELAKANG MASALAH}

Salah satu unsur strategis yang menopang pertumbuhan perekonomian negara adalah kegiatan perbankan, karena bank merupakan lembaga yang berfungsi menghimpun dan menyalurkan dana masyarakat. Sebagai sebuah lembaga keuangan yang berorientasi bisnis bank memiliki banyak produk layanan yang berhubungan dengan bidang keuangan, dari produk-produk perbankan tersebut kredit merupakan produk yang menjadi prioritas dalam bisnis perbankan, bunga dari kredit yang disalurkan kepada masyarakat merupakan salah satu sumber pendapatan terbesar bank. Penyaluran kredit yang diberikan oleh bank kepada masyarakat merupakan dana yang berasal dari masyarakat yang berupa simpanan baik dalam bentuk tabungan, giro atau deposito. Penyaluran kredit kepada masyarakat oleh perbankan selain merupakan bidang usaha yang dapat memberikan keuntungan yang besar namun juga memberikan resiko yang tidak kecil bagi usaha perbankan, maka dari itu untuk memberikan kredit tersebut bank harus juga memperhatikan unsur-unsur keamanan agar usaha perbankan dapat berjalan dengan baik.

Menurut undang-undang perbankan kredit adalah "penyediaan uang atau tagihan yang dapat dipersamakan dengan itu berdasarkan persetujuan atau kesepakatan pinjam meminjam antara bank dengan pihak lain yang mewajibkan pihak peminjam untuk melunasi hutangnya setelah jangka waktu tertentu dengan bunga, imbalan atau pembagian hasil keuntungan". ${ }^{1}$

Dalam memberikan kredit unsur utama dari kredit adalah kepercayaan, kepercayaan dari pihak bank selaku pemberi kredit dan nasabah selaku penerima kredit, kepercayaan pihak bank tersebut tidak didapatkan oleh bank secara semata-mata namun timbul dari terpenuhinya syarat-syarat yang diberikan bank kepada calon nasabah (debitur), dengan terpenuhinya persyaratan-persyaratan yang telah ditetapkan tersebut maka pihak bank akan memiliki keyakinan bahwa kredit yang diberikan kepada debitur akan kembali sesui dengan jangka waktu yang telah disepakati.

Thomas Suyanto dalam bukunya "Dasar-dasar Perkreditan" mennyatakan bahwa unsur-unsur kredit terdiri dari :

\footnotetext{
${ }^{1}$ Muhamad Djumanha, Hukum Perbankan di Indonesia, Citra Aditya Bakti, Bandung, 1996, h. 180
} 
1. Kepercayaan, "dalam hal ini kreditur memiliki keyakinan bahwa debitur akan dapat memenuhi prestasinya sesuai dengan kesepakatan.

2. Tenggang waktu, Penentuan batas waktu kapan debitur debitur harus memenuhi prestasinya"

3. "Degree of risk", Resiko yang harus ditanggung kreditur atas pemenuhan prestasi oleh debitur dalam jangka waktu tertentu.

4. Prestasi, Merupakan objek dalam perjanjian kredit dimana dapat berupa uang maupun berupa pemberian barang dan pelaksanaan jasa. ${ }^{2}$

Asas pemberian kredit adalah atas dasar kepercayaan, pemberian kredit oleh bank merupakan pemberian kepercayaan kepada masyarakat. Karena pemberian kredit merupakan bentuk jasa perbankan yang dimaksudkan untuk mendapatkan keuntungan, maka bank dalam menyalurkan kredit kepada masyarakat haruslah benar-benar memperhatikan kemampuan dari penerima kredit. Agar kredit dapat berjalan dengan baik bank haruslah melakukan analisa mendalam terkait faktor kemampuan dan kemauan nasabah dalam mengembalikan pinjaman.

Agar tujuan pemberian kredit dapat terpenuhi dan prestasi dapat kembali sesuai dengan jangka waktu yang ditentukan, Prinsip kehati-hatian perlu diperhatikan dalam menjalankan usaha perbankan, terutama dalam penyaluran dana kemasyarakat/kredit bank haruslah melakukan analisis yang mendalam, mulai dari proses awal pengajuan kredit sampai pencairan kredit, proses perjanjian dan pemenuhan dokumen-dokumen kredit yang lengkap. Menurut aturan yang termaktub dalam pasal 2 UU Nomor 10 Tahun 1998 Tentang Perbankan disebutkan "bahwa perbankan dalam melakukan usahanya berdasar demokrasi ekonomi dan prinsip kehati-hatian." Penerapan prinsip kehati-hatian dalam proses analisa kredit penyaluran dana ke masyarakat akan meminimalisir resiko dalam kredit yang akan disalurkan. Resiko kredit adalah kerugian yang disebabkan oleh debitur dalam jangka waktu yang telah disepakati tidak dapat mengembalikan hutang yang dipinjam kepada bank.

Tujuan bank untuk memperoleh keuntungan dari pemberian kredit pada nasabah harus juga diseimbangkan dengan tujuan likuiditas dan solvabilitas bank, sehingga dapat

\footnotetext{
${ }^{2}$ Hermansyah, Hukum Perbankan Nasional Indonesia, Prenana Media, Jakarta, 2005, h.59
} 
menjamin terbayarnya hutang-hutang tersebut baik dalam jangka pendek maupun jangka panjang. Untuk itu untuk mengurangi resiko maka bank dalam menyalurkan kredit haruslah hati-hati, bank harus menyelidiki apakah calon nasabah benar dapat dipercaya dan mampu mengembalikan pinjaman sesuai jangka waktu kredit. Analisa kredit perbankan dapat dilakukan dengan menggunakan rumus lima $\mathrm{C}$ yaitu meliputi, Character (sifat calon debitur), Capital (modal dasar calon debitur), Capacity (kemampuan debitur), Collateral (Jaminan yang disediakan), dan Condition of economi (kondisi perekonomian). ${ }^{3}$

Dalam menyalurkan kredit kepada masyarakat akan membawa resiko kredit, yang dimaksud dengan risiko kredit adalah "risiko kerugian sehubungan dengan pihak peminjam tidak dapat dan atau tidak mau memenuhi kewajiban untuk membayar kembali dana yang dipinjamnya secara penuh pada saat jatuh tempo atau sesudahnya". ${ }^{4}$ Dalam kegiatan kredit perbankan proses analisa kredit adalah salah proses terpenting yang harus dilakukan secara cermat oleh pihak bank karena melalui proses analisa yang baik akan mengurangi resiko dalam proses kredit perbankan.

Selain melaui proses analisa kredit yang baik guna mengurangi resiko upaya lain yang dapat dilakukan adalah dengan adanya jaminan dalam proses kredit perbankan, meskipun tidak wajib namun keberadaan jaminan dalam bidang perkreditan dipandang penting, karena akan menjamin terpenuhinya pengembalian dana kredit yang dikeluarkan. Agar pihak bank memiliki keyakinan bahwa debitor akan memenuhi prestasinya, adanya jaminan dari harta kekayaan debitor dalam perjanjian kredit merupakan upaya preventif dari bank bahwa kredit yang telah dicairkan akan dikembalikan oleh pihak debitor.

Agar benda dapat dijaminkan dalam perjanjian kredit syarat haruslah memenuhi syarat-syarat tertentu yaitu memiliki nilai ekonomis dan harus dapat dipindah tangankan, Pada Pasal 499 KUHPer diberikan pengertian tentang benda " yang dinamakan kebendaan ialah tiap-tiap barang dan tiap-tiap hak yang dapat dikuasai oleh hak milik". Benda dalam ranah hukum perdata dapat memiliki makna baik sebagai barang maupun hak, dalam konteks tersebut barang merupakan sesuatu yang berwujud sedangkan hak adalah mengenai benda yang tidak berwujud.

\footnotetext{
${ }^{3}$ Suharnoko, Hukum Perjanjian Teori Analisa dan Kasus, Kencana, Jakarta, 2015 h.230.

4 Ferry N.Idroes, Manajemen Risiko Perbankan: Pemahaman Pendekatan 3 Pilar Kesepakatan Basel II Terkait Aplikasi Regulasi dan Pelaksanaanya Di Indonesia, Rajawali Press, Jakarta , 2008,h.,22
} 
Dalam aturan yang termuat dalam KUHPer pembagian benda cukuplah luas, benda yang diatur dalam KUHPer :

a. Pasal 503 KUHPer, "benda berwujud dan benda tidak berwujud"

b. Pasal 505 KUHPer "benda habis pakai dan benda tidak habis pakai";

c. Pasal 1332 KUHPer "Benda dalam perdagangan dan benda di luar perdagangan";

d. Pasal 1334 KUHPer "Benda yang telah ada dan benda yang baru aka nada";

e. Pasal 1694 KUHPer "benda yang dapat dibagi dan tidak dapat dibagi-bagi";

f. Pasal 1163 KUHPer "benda yang dapat diganti dan tidak dapat diganti”;

g. Pasal 504 KUHPer "benda bergerak dan benda tidak bergerak".

Dalam ketentuan yang diatur dalam KUHPer. Tentang jaminan kredit dibedakan dalam beberapa bentuk menurut sifatnya, jenis jaminan yang diatur dalam KUHPer :

a. Jaminan Umun, sebagaimana seperti yang diatur dalam pasal 1131 KUHPer "bahwa segala kebendaan si berutang baik yang bergerak maupun tidak bergerak baik yang sudah ada maupun akan ada di kemudian hari menjadi tanggungan untuk segala perikatan perorangan.” Jaminan ini merupakan jaminan yang sudah ditetapkan oleh undang-undang yang tanpa diperjanjikan pun secara otomatis telah mengikat para pihak.

b. Jaminan khusus, sebagaimana yang diatur dalam pasal 1820-1850 KUHPer jaminan ini lahir karena diperjanjikan oleh para pihak baik berupa jaminan kebendaan maupun jaminan perorangan.

Dalam praktek pembebanan jaminan atas hutang debitur terdapat beberapa lembaga jaminan yang mengatur pengikatan jaminan, yaitu :

a. "Hak tanggungan", sebagaiman aturan yang disebutkan dalam undang-undang nomor 4 tahun 1996 tentang "hak tanggungan atas tanah beserta benda-benda yang berkaitan dengan tanah"

b. "Hipotik", sebagaimana yang diatur dalam pasal 1162-1232 KUHPer.

c. Gadai “(Pand)”,sebagaimana yang diatur dalam pasal 1150-1160 KUHPer. 
d. "Jaminan Fidusia Sebagaimana ditetapkan dalam UU Nomor 42 Tahun 1999 tentang Jaminan Fidusia.

Benda bergerak baik benda bergerak berwujud maupun tidak berwujud dapat dijadikan jaminan dalam lembaga jaminan gadai dan lembaga jaminan fidusia, maka dalam hal ini piutang yang merupakan salah satu bentuk benda bergerak tidak berwujud dapat dijadikan jaminan atas hutang debitur. Di Indonesia setelah diberlakukannya peraturan tentang fidusia yaitu UU Nomor 42 Tahun 1999 cakupan jaminan fidusia lebih diperluas sehingga yang menjadi obyek jaminan fidusia termasuk benda bergerak yang berwujud dan benda bergerak tidak berwujud termasuk juga benda bergerak yang tidak dapat dibebani dengan hak tanggungan atas tanah beserta benda-benda yang berkaitan dengan tanah ${ }^{5}$.

Menurut aturan yang dimuat dalam UU Nomor 42 Tahun 1999 Tentan Jaminan Fidusia Pada Pasal 1 angka 4 disebutkan bahwa "Benda adalah segala sesuatu yang dapat dimiliki dan dialihkan, baik benda itu berwujud maupun tidak berwujud, terdaftar maupun tidak terdaftar, bergerak maupun tidak bergerak yang tidak dapat dibebani dengan hak tanggungan atau hipotik".

\section{RUMUSAN MASALAH}

Berdasarkan uraian yang telah diurai diatas maka permasalahan yang akan dikaji dalam penulisan ini adalah bagaimana aspek hukum atas piutang sebagai obyek jaminan kredit!

\section{METODE PENELITIAN}

Dalam setiap penulisan karya ilmiah penggunaan metode penelitian merupakan suatu syarat agar didapatkan hasil sesuai dengan isu yang dikemukakan, maka untuk menjawab permasalahan dalam penulisan karya ilmiah ini tipe penelitian yang digunakan adalah Yuridis Normatif. Penulisan yang dilakukan sesuai dengan prosedur ilmiah sehingga dapat menjawab permasalahan, memahami hukum yang terkandung dalam norma dan kaidah dari sudut pandang teori dan keilmuan hukum.

Untuk mendukung penggunaan tipe penelitian tersebut pendekatan masalah digunakan pendekatan undang-undang. Pendekatan undang-undang digunakan dalam

\footnotetext{
${ }^{5}$ Sri Soedewi Masjchun, Himpunan Karya Hukum Jaminan, Liberty, Yogyakarta, 2001, h.21.
} 
penulisan ini karena fokus dari penelitian adalah kajian terhadap norma/aturan hukum yang terkait dengan perjanjian jaminan perbankan.

\section{PEMBAHASAN}

Dalam menjalankan roda perekonomian, peran lembaga perbankan sangatlah penting dimana melalui fasilitas kreditnya sangat membatu kegiatan perekonomian negara melalui fasilitas kredit perbankan. Agar bisa mendapat kredit dari lembaga perbankan diperlukan beberapa persyaratan yang harus dipenuhi oleh calon debitur dalam mengajukan permohonan kredit, pemenuhan berbagai persyaratan tersebut merupakan suatu upaya pengaman bagi pihak bank supaya prestasi debitur dapat dipenuhi dalam jangka waktu yang telah disepakati. Salah satu upaya pihak bank dalam memberikan proteksi terhadap dana yang sudah dikeluarkan pada debitur adalah dengan diadakannya jaminan kredit perbankan, untuk itu hukum telah menyediakan sarana sebagaimana yang telah diatur dalam ketentuan hukum jaminan guna memberikan proteksi bagi kreditur tersebut hukum telah memberikan aturan-aturan yang dimuat dalam aturan perundang-undangan. Dalam teori yang terkandung dalam praktek hukum perjanjian khususnya mengenai kredit, perjanjian jaminan/tanggungan merupakan perjanjian tambahan sedangkan perjanjian pokoknya adalah perjanjiann kredit, hal ini memberikan pengertian bahwa adanya perjanjian jaminan tergantung pada perjanjian kredit.

Dalam praktek perbankan khususnya dalah ranah usaha kredit perbankan, dalam teori hukum dasar atas perjanjian kredit yang dibuat antara para pihak adalah kepercayaan, dalam hal ini kreditur selaku pemberi kredit harus memiliki kepercayaan pada debiturnya, bahwa debitur akan mampu mengembalikan dana yang telah diterima sesuai dengan jangka waktu yang telah disepakati dalam perjanjian yang dibuat. Dalam praktek guna menjaga kelangsungan proses usaha dunia perbankan khususnya dalam hal penyaluran dana kepada masyarakat, hukum sebagai perangkat negara yang bertugas mengatur seluruh proses kehidupan dalam suatu negara telah memberikan suatu sistem proteksi agar dana yang telah dikucurkan kepada masyarakat dalam bentuk kredit oleh bank tidak menjadi kredit yang bermasalah. Aturan-aturan tersebut secara umum ditetapkan dalam buku ke II Kitab Undang-Undang Hukum Perdata.

Di dalam aturan hukum perdata dalam pasal 1131 KUHPer disebutkan "segala kebendaan si berutang, baik yang bergerak maupun yang tak bergerak, baik yang sudah ada 
maupun yang baru akan ada, menjadi jaminan untuk perikatan-perikatan perorangan".ketentuan yang termuat dalam pasal 1131 KUHPer merupakan suatu bentuk jaminan secara umum yang lahir secara otomatis dari perjanjian kredit yang dibuat oleh para pihak, dalam hal ini Undang-undang memberikan perlindungan dengan kedudukan yang sama bagi semua kreditur. Adanya jaminan dalam proses perjanjian kredit merupakan upaya untuk memberikan kepastian akan pelunasan hutang oleh debitur sebagai sarana perlindungan keamanan dan perlindungan bagi kreditur.

Selanjutnya dalam pasal 1132 KUHPer dinyatakan :'barang-barang tersebut menjadi jaminan secara bersama bagi seluruh kreditur yang terhadap hasil penjualan barang-barang tersebut dibagi menurut perbandingan piutang masing-masing kreditur kecuali jika diantara kreditur ada alasan-alasan sah untuk didahulukan". Ketentuan ini mengatur bahwa untuk jaminan umum akan dibagikan secara berimbang kepada seluruh kreditur atau berlaku asas paritas kreditorum. Kedudukan kreditur adalah sebagai kreditur konkuren kecuali apabila kedudukan kreditur tersebut sebagai "kreditur preferent" yang memiliki hak-hak untuk didahulukan.tersebut. ${ }^{6}$

Dalam praktek jaminan secara umum memiliki kelemahan bagi kreditur karena tidak ada jaminan kebendaan khusus untuk jaminan pelunasan hutang oleh debitur, karena disisni semua kreditur memiliki kedudukan yang sama terhadap benda-benda milik debitur sehingga apabila jumlah lelang benda-benda milik debitur lebih kecil dari dari jumlah pinjamannya atau karena banyaknya kreditur yang berkepentingan atas harta benda yang dimiliki oleh seorang debitur, sehingga berakibat pengembalian hutang kreditur tidak akan dapat kembali secara utuh.

Sarana hukum yang diatur dalam pasal 1131 KUHPerdata dirasa belum mampu memberikan perlindungan yang maksimal bagi kreditur, kelemahan dari jaminan umum ini perlu didukung oleh sarana peraturan undang-undang yang mampu memberikan keamanan dan perlindungan yang lebih pasti bagi kreditur. Untuk itu pembentuk Undang-undang memberikan piranti jaminan khusus guna memberi perlindungan bagi kreditur, jaminan yang diberikan debitur atas dasar perjanjian dengan kreditur yang dapat berupa jaminan kebendaan maupun jaminan perorangan merupakan bentuk dari perjanjian khusus, dimana

\footnotetext{
${ }^{6}$ Ibid, h.32
} 
dalam hal ini kreditur memiliki hak untuk didahulukan atas benda yang dijadikan obyek jaminan. ${ }^{7}$ Perjanjian jaminan khusus ini memiliki tingkat keamanan yang lebih baik kepada kreditur karena ia memiliki hak yang didahulukan atas benda jaminan tersebut, berbeda dengan jaminan umum sebagaimana yang diatur dalam pasal 1131 KUHPer terhadap harta kekayaan debitur dibagi secara rata kepada para kreditur sesuai dengan prosentase piutang. Sesuai dengan ketentuan dalam peraturan hukum perdata khususnya hukum jaminan perjanjian jaminan timbul karena adanya perjanjian kredit karena secara teori perjanjian jaminan merupakan jaminan tambahan dan perjanjian kredit merupakan perjanjian pokok, sehingga ada tidaknya perjanjian jaminan sangat tergantung atas perjanjian kredit sebagi perjanjian pokok.

Karena merupakan bentuk perjanjian tambahan sebagaimana telah diurai sebelumnya, perjanjian jaminan memiliki kedudukan dan akibat hukum $:^{8}$

a. keberadaannya tergantung pada keberadaan perjanjian pokok

b. berahkirnya perjanjian tergantung perjanjian pokok

c. Apabila perjanjian pokok batal maka perjanjian jaminan ikut batal;

d. Apabila perjanjian pokok beralih maka perjanjian jaminan juga ikut beralih ikut beralih juga perjanjian jaminan;

e. Dalam hal perjanjian pokok beralih karena cessi, subrograsi, maka perjanjian jaminan juga ikut beralih tanpa adanya penyerahan khusus.

Perjanjian jaminan seperti yang telah diuraikan sebelumnya merupakan bentuk perjanjian tambahan yang keberadaannya mengikuti perjanjian pokok yaitu perjanjian kredit, Pengertian perjanjian jaminan kebendaan menurut subekti : "pemisahan suatu bagian harta kekayaan debitur berupa jaminan kebendaan sebagai jaminan atas pelunasan/pembayaran kewajiban dari debitur terhadap kreditur". 9 Pemberian jaminan kebendaan dari deditur atas hutangnya pada kreditur merupakan perbuatan pemisahan atas harta kekayaan yang dimiliki debitur untuk pemenuhan prestasinya pada kreditur. Dari pengertian tersebut memberikan acuan bahwa jaminan kebendaan merupakan suatu hak

\footnotetext{
${ }^{7}$ Op.Cit, Suharnoko, h. 43

${ }^{8}$ Sri Soedewi Masjchun, Himpunan Karya Tentang Hukum Jaminan, Liberty, Yogyakarta, 1998 h.143

9 Subekti, Jaminan-jaminan Untuk pemberian Kredit, Menurut Hukum Indonesia, Alumni, Bandung, 1982,h.27
} 
jaminan yang melekat pada suatu benda milik debitur namun bukan kepada seluruh benda milik debitur namun hanya benda tertentu milik debitur yang dijadikan jaminan dalam kesepakatan dari debitur dan kreditur dalam sebuah perjanjian. Benda sebagai obyek jaminan memiliki pengertian bahwa dalam hal ini debitur telah melepaskan sebagian kekuasaanya atas benda tersebut, yang dilepaskan adalah kekuasaan untuk memindahkan hak atas benda tersebut pada kreditur. Dengan diberikan jaminan kebendaan pada kreditur atas dana yang telah dikeluarkan kepada debitur, akan menempatkan posisi kreditur sebagai seorang kreditur preferent, yaitu kreditur yang memiliki hak untuk didahulukan dari kreditur lainnya terhadap benda obyek jaminan sebagai pelunasan hutang debitur. Dalam hal pailitpun benda yang dijadikan jaminan dalam perjanjian kredit tidak berpengaruh terhadap pemegang atas hak jaminan tersebut.

Jika kita perhatikan perbuatan perjanjian para pihak tersebut merupakan penyimpangan dari pasal 1131 KUHPerdata yang mengatur jaminan secara umum terhadap benda milik debitur, perjanjian jaminan ini diadakan dengan maksud untuk memberikan hak jaminan secara khusus terhadap benda tertentu milik debitur guna pelunasan hutangnya pada kreditur. Dengan adanya jaminan kebendaan secara khusus ini memberikan akibat bahwa kreditur dalam perjanjian ini menjadi seorang kreditur preferen, yaitu kreditur yang memiliki hak diutamakan/didahulukan terhadap kreditur-kreditur lain terhadap benda yang dijandikan obyek jaminan dalam perjanjian kredit. Dalam keadaan pailitpun kreditur preferen dapat bertindak bahwa seakan-akan benda jaminan tersebut tidak masuk dalam boedel pailit, benda sebagai obyek jaminan tidak didaftar sebagai harta kepailitan, kreditor preferen disini merupakan kreditor separatis. ${ }^{10}$

Jaminan kebendaan adalah "jaminan yang berupa hak yang melekat pada suatu benda yaitu benda tertentu milik debitor yang lahir akibat adanya kesepakatan antara debitor dan kreditor, dapat dipertahankan, selalu mengikuti bendanya dan dapat dialihkan". Dengan adanya perjanjian jaminan kebendaan tersebut merupakan penyimpangan atas peraturan pasal 1131 KUHPer yaitu jaminan umum dimana seluruh harta debitur adalah jaminan atas hutang-hutangnya, dalam jaminan kebendaan hanya melekat pada benda tertentu milik debitor yang telah disepakati dan diikat oleh parjanjian jaminan. Karena

${ }^{10}$ Djuhaendah Hasan I, Op.cit.h.237 
diikat oleh perjanjian jaminan kreditur sebagai pemegang jaminan kebendaan diberikan hak kebendaan yang memiliki ciri-ciri yang diistimewakan. Adapun ciri pokok dari hak kebendaan itu adalah: ${ }^{11}$

1. Merupakan "Hak kebendaan bersifat mutlak"

2. Ada "droit de suite"

3. "Ada preferensi"

4. "Mengandung asas prioritas".

Bank sebagai sebuah lembaga keuangan memiliki peran yang penting dalam menunjang pembangunan perekonomian suatu negara, salah satu bentuk usaha perbankan yang penting dalam kehidupan adalah penyaluran dana pinjaman (kredit) kepada masyarakat. Dalam memberikan kredit kepada masyarakat lembaga perbankan memerlukan suatu bentuk peraturan sebagai pengaman untuk menjaga apabila kredit yang diberikan tersebut mengalami masalah, untuk mengantisipasi hal tersebut undang-undang memeberikan sarana yaitu dengan adanya sebuah lembaga jaminan kebendaan.

Diaturnya lembaga jaminan kebendaan dalam UU Nomor 10 Tahun 1998 tentang Perbankan dalam pasal 8 ayat (1) dinyatakan: "bahwa bank dalam memberikan kredit atau pembiayaan berdasarkan prinsip syariah, bank umum wajib mempunyai keyakinan berdasarkan analisis yang mendalam atas itikad dan kemampuan serta kesanggupan nasabah debitor untuk melunasi utangnya atau mengembalikan pembiayaan dimaksud sesuai dengan yang diperjanjikan”. Prinsip yang diatur dalam pasal tersebut menunjukan teori yang disebut dengan "The Five C's of Credit" dimana dalam teori tersebut salah satunya unsurnya adalah "Collateral" yaitu jaminan yang harus diberikan oleh pihak debitor atas risiko yang diterima kreditor atas dana yang telah dikeluarkan. "Dalam hal ini jika jaminan tambahan diberikan oleh debitor kepada bank guna diadakannya kredit berdasarkan prinsip-prinsip syariah, maka jaminan tersebut disebut dengan agunan" (vide Pasal 1 angka 23 Undang-undang Perbankan). Dengan demikian dapat diartikan bahwa: “jaminan adalah harta kekayaan debitur yang dijadikan suatu tanggungan kepada kreditor

11 I Ketut Oka Setiawan, Hukum Perorangan dan Kebendaan, Sinar Grafika,Jakarta, 2016 h.44 
untuk menjamin pelaksanaan kewajibannya yaitu pemenuhan prestasi dalam suatu perikatan". 12

Dalam penjelasan Pasal 8 UU Perbankan disebutkan: "bahwa apabila keberadaan jaminan pokok sudah menyakinkan bank maka bank tidak perlu meminta jaminan tambahan". Dalam praktek yang terjadi di lapangan dalam hal adanya kredit perbankan, bank mensyaratkan adanya jaminan pokok dan jaminan tambahan sehingga bank memiliki proteksi atas kredit yang telah dikeluarkan. ${ }^{13}$ Adanya jaminan yang diberikan oleh debitur (nasabah) kepada kreditur dalam hal ini pihak bank merupakan bentuk proteksi/pengaman bagi pihak bank, bank menjadi memiliki keyakinan bahwa debitur akan melaksanakan prestasi sesuai kesepakatan yang telah ditetapkan antara debitur dan pihak bank. Namun demikian secara teori sebenarnya jaminan bukanlah syarat utama dalam pelaksanaan perjanjian kredit perbankan tersebut banyak faktor yang akan dinilai oleh pihak bank sebelum bank mengucurkan dananya pada pihak debitur.

Dalam hukum perjanjian kredit dapat kita lihat bahwa pada dasarnya jaminan memiliki fungsi sebagai sarana perlindungan yang diberikan pada dana yang dikelola bank, dimana dana yang dikelola bank tersebut adalah dana masyarakat sehingga bank memerlukan proteksi-proteksi khusus terhadap dana yang dikelola. Dalam hal ini dapat disimpulkan bahwa fungsi pokok jaminan antara lain, meliputi $:{ }^{14}$

a. Untuk menjaga dana bank yang disalurkan kepada masyarakat dalam bentuk kredit, dengan adanya jaminan yang diberikan oleh pihak debitur pada pihak bank selaku kreditur maka bank memiliki hak khusus dari penjualan obyek/benda jaminan tersebut;

b. Dengan adanya jaminan yang diberikan maka akan memberikan tanggungjawab kepada debitor untuk memenuhi kewajibannya yaitu pelaksanaan prestasi.

Benda bergerak tidak berwujud menurut ajaran yang termuat dalam KUHPerdata salah satun bentuknya adalah piutang, proses penyerahan benda bergerak menurut KUHPer diantaranya :

\footnotetext{
12 Mariam Darus Badrulzaman, "Beberapa Permasalahan Hukum Hak Jaminan,” Jurnal Hukum Bisnis, Volume 11, 2000, h.12

${ }^{13}$ Remy Sutan Sjahdeini, Hak Tanggungan, Asas-Asas Ketentuan Pokok dan Masalah Ynag dihadapi Perbankan, Refika Aditama, Bandung, 2004, h.65

${ }^{14}$ Moch.Isnaeni, Hukum Jaminan Kebendaan, LaksBang, Jakarta, 2016, h.51.
} 
1. Surat Piutang Atas Nama, "surat piutang atas bawa pembayaran hanya dapat diterima oleh orang dimana namanya tersebut dalam surat tersebut" ${ }^{15}$ proses penyerahan piutang atas nama ini dilakukan dengan cara "cessie" Pasal 613 (1) BW, cessie dapat dibuat dengan dua cara yaitu secara akta otentik (dibuat Notaris), atau dapat dibuat bawah tangan dimana dinyatakan bahwa piutang telah dipindahkan pada orang lain. ${ }^{16}$

2. Surat Piutang Atas Bawa, "dalam surat piutang atas bawa pembayaran dapat diberikan kepada siapa saja yang membawa surat tersebut. ${ }^{17}$ Penyerahannya surat piutang atas bawa ini dilakukan dengan cara penyerahan nyata yaitu penyerahan dari pemilik lama ke pemilik baru".

3. Surat Piutang Atas Tunjuk, "merupakan surat yang menyatakan tentang pembayaran uang kepada orang yang namanya telah ditunjuk untuk menerima pembayaran tersebut". ${ }^{18}$ Dalam surat piutang atas tunjuk penyerahan dilakukan dengan cara penyerahan surat itu dan disertai dengan endossement.

Dalam ketentuan yang ada di Pasal 1152 (1) jo. Pasal 1152 bis dan Pasal 1153 KUHPer dapat disimpulkan bahwa piutang dapat dipergunakan sebagai jamian atas suatu hutang. Piutang yang dapat berupa surat piutang atas bawa dan surat piutang atas tunjuk yang merupakan bentuk dari benda bergerak tidak berwujud tidak hanya berfungsi sebagai alat bukti saja namun juga memiliki fungsi sebagai alat tagih terhadap pembayaran sejumlah uang. Jadi tanpa adanya surat tersebut seseorang tidak dapat mengatakan bahwa dirinya memiliki hak tagih "aan tooder atau aan order". Ketentuan tersebut mensyaratkan bahwa debitur menggadaikan piutang berupa surat dan hak tagih atas piutang tersebut. Namun untuk tagihan dalam surat "aan order" agar surat tersebut dapat dipindahkan terhadap orang lain harus melalui endossement, tanpa endossement hak tagih dalam surat

\footnotetext{
${ }^{15}$ Frieda Husni Hasbullah, Hukum Kebendaan Perdata Hak-Hak Yang Memberi Kenikmatan, Jilid I, IndHill-Co, Jakarta, 2005, h.127

${ }^{16}$ Ibid.h.128

${ }^{17}$ Ibid,h. 129

${ }^{18}$ Wiryono Projodikoro, Hukum Wesel, Aksep dan Cek di Indonesia, Bale Bandung, bandung, 1998,h. 15
} 
tersebut tidak dapat dilaksanakan. Dengan demikian sudah tentu jika surat tagihan "aan order" penyerahannya kepada pemegang gadai harus disertai dengan endossement ${ }^{19}$

Dalam hal jaminan gadai yang berupa piutang atas nama maka orang yang memiliki hak atas gadai tersebut harus mengetahui adanya gadai dalam hal ini harus ada pemberitahuan secara tertulis dan izin dari pemberi gadai. Dalam praktek pengikatan jaminan atas suatu piutang cessie lebih disukai oleh lembaga perbankan, dengan cessie pihak bank/kreditur sebagai cessionaris akan menerima seluruh akibat hukum yang muncul dari diterbitkannya cessie. Keuntungan yang didapat adalah dalam cessie untuk peralihannya debitur tidaklah perlu diberi tahu berbeda dengan gadai apabila ada peralihan maka debiturnya harus mengetahui. Dalam perkembangan kredit perbankan khususnya dalam hal kredit lembaga gadai sudah mulai tergeser oleh cessie. Pemegang benda gadai ketika terjadi penyerahan cessie bukanlah memberikan hak padanya sebagai pemilik benda gadai tersebut, cessie merupakan suatu upaya dalam pengalihan piutang atas nama.

Jaminan benda bergerak tidak berwujud dalam hal ini piutang sebagai jaminan dalam lembaga gadai sesuai dengan aturan yang berlaku bahwa obyek piutang dalam lembaga gadai berupa surat piutang atas nama, surat piutang atas bawa serta surat piutang atas tunjuk. Dalam perjanjian gadai antara pihak kreditur dan kreditur tidak disyaratkan secara tegas bentuk perjanjian yang harus digunakan oleh para pihak, disisni para pihak bebas memilih apakah perjanjian mereka dibuat dalam bentuk akta outentik maupun dalam bentuk akta dibawah tangan.

Dalam lembaga jaminan fidusia dimana aturanya termaktub dalam UU No. 42 Tahun 1999 tentang Jaminan Fidusia, dalam hal ini terhadap jaminan fidusia tersebut dapat diberikan terhadap satu atau lebih satuan benda termasuk juga terhadap piutang baik yang telak ada saat ini ataupun yang baru akan ada kemudian hari. Jadi selain lembaga gadai lembaga fidusiapun mengcover jaminan atas benda bergerak tidak berwujud. Tidak seperti aturan yang dijelaskan dalam lembaga gadai yang menjelaskan secara jelas piutang mana yang dapat dibebani dengan gadai, namun dalam perjanjian fidusia tidak ditentukan secara jelas piutang apa yang dapat dibebani jaminan fidusia. Yang menjadi standart umum adalah bahwa piutang sebagai benda bergerak tidak berwujud haruslah memenuhi standart bahwa

${ }^{19}$ Munir Fuady, Hukum Perbankan Moden, Citra Aditya Bakti, Bandung, 1999, h.106 
benda yang dapat dijadikan jaminan adalah benda tersebut harus mempunyai nilai ekonomi dan dapat dialihkan/dipindah tangankan.

Jaminan fidusia dalam proses penyerahan hak milik, adalah penyerahan hak secara yuridis dengan maksud sebagai jaminan atas adanya perjanjian pokok antara kreditur dan kreditur yaitu perjanjian kredit. jadi dalam perjannjain fidusia yang diserahkan hanyalah hak atas benda sebagai jaminan atas hutang, tidak menyerahkan hak kepemilikan benda tersebut dari pihak debitur (pemberi fidusia) dan kreditur (penerima fidusia). Dalam lembaga jaminan fidusia proses perjanjian jaminan kebendaan dalam hal ini piutang haruslah dibut secara autentik dan didaftarkan di kantor pendaftaran fidusia sehingga akan terbit akta jaminan fidusia. Pada Pasal 1 angka 3 Undang-Undang Jaminan Fidusia memberikan definisi bahwa "piutang adalah hak untuk menerima pembayaran". Sedangkan mengenai jenis-jenis piutang yang dapat dijadikan sebagai obyek jaminan fidusia tidak diatur secara detail dalam Undang-Undang Jaminan Fidusia.

Dari berbagai teori hukum menganai hukum jaminan, dapat dikemukakan bahwa maksud utama diadakannya jaminan dalam perjanjian kredit adalah sebagai jaminan pelunasan atas hutang debitur kepada kreditur. Dalam jaminan kebendaan penerima jaminan tidak serta merta sebagai pemilik atas obyek/benda yang dijandikan jaminan atas hutang debitur, ketika debitur wanprestasi tidak serta merta benda tersebut menjadi milik kreditur namun akan melalui proses penjualan benda obyek jaminan dan hasil atas penjualan tersebut akan diperhitungkan guna melunasi hutang-hutang debitur. Demikian dalam jaminan dengan obyek benda bergerak tidak berwujud dalam hal ini piutang maka ketika debitur mengalami wanprestasi maka obyek jaminan yang berupa piutang tersebut akan dicairkan dan digunakan sebagai pelunasan atas hutang debitur.

\section{KESIMPULAN}

Dalam lalu lintas praktek dunia perbankan khususnya dalam hal perjanjian kredit merupakan sektor yang menunjang sistem perekonomian suatu negara. Secara umum dasar dari pemberian kredit adalah adanya kepercayaan, namun untuk menjamin kredit yang diberikan oleh bank tidak mengalami masalah salah satu upaya yang dapat dilakukan 
adalah dengan melakukan perjanjian jaminan kebendaan terhadap dana yang dikucurkan ke masyarakat dalam bentuk kredit.

Dalam aturan yang termuat dalam KUHPerdata perjanjian kebendaan dapat berupa perjanjian benda tidak bergerak dan benda bergerak, lebih lanjut benda bergerak dibagi kembali menjadi benda bergerak berwujud dan benda bergerak tidak berwujud. Dalam hal ini yang termasuk dalam benda bergerak tidak berwujud yang dapat dijadikan jaminan atas suatu hutang adalah piutang dimana lembaga jaminan yang dapat digunakan adalah lembaga gadai dan lembaga jaminan fidusia.

Dalam proses perjanjian piutan sebagai jaminan hutang debitur dalam lembaga jaminan fidusia perjanjian haruslah dibuat secara autentik dan didaftarkan di kantor pendaftaran fidusia agar terbit akta janminan fidusia sedangkan dalam gadai tidak ada ketentuan yang mengatur bentuk dari perjanjian antara pihak kreditur dan debitur jadi para pihak bebas menentukan apakah perjanjian mereka akan dibuat dalam akta autentik ataupun dalam bentuk akta dibawah tangan. 


\section{DAFTAR PUSTAKA}

\section{Buku :}

Andi Prayitno, Hukum Fidusia Problematika Yuridis Pemberlakuan UU No. 42 Tahun 1999, Bayu Media, Malang, 2009.

Gandapradja,Permadi Dasar dan Prinsip Pengawasan Bank, Gramedia Pustaka Utama, Jakarta,2004

Idroes, Ferry N, Manajemen Risiko Perbankan: Pemahaman Pendekatan 3 Pilar Kesepakatan Basel II Terkait Aplikasi Regulasi dan Pelaksanaanya Di Indonesia, Rajawali Press, Jakarta, 2008

Ibrahim,Johannes, Cross Default \& Cross Collateral Dalam Upaya Penyelesaian Kreedit Bermasalah, Refika Aditama, Bandung, 2004

I Ketut Oka Setiawan, Hukum Perorangan dan Kebendaan, Sinar Grafika, Jakarta, 2016

J.Satrio, Hukum Jaminan Hak jaminan Kebendaan, Citra Aditya Bakti, Bandung, 2002

Mariam Darus Badrulzaman, Bab-Bab Tentang Credit Verband, Gadai, dan fidusia. Alumni, Bandung, 1981

Moch.Isnaeni, Hukum Jaminan Kebendaan, Laksbang, Jakarta, 2016.

Peter Mahmud Marzuki, Hukum Jaminan Indonesia, Elips, Jakarta 1998.

Sutojo,Siswanto Analisa Kredit Bank Umum: Konsep dan Tehnik, Pustaka Binaman Pressindo, Jakarta,1995

Sofwan,Sri Soedewi Masychun, Hukum Benda, Liberty, Yogjakarta, 1981

Subekti, Jaminan-jaminan Untuk pemberian Kredit, Menurut Hukum Indonesia, Alumni, Bandung, 1982

R.Subekti, R.Tjitrosudibio, Kitab Undang-Undang Hukum Perdata, terjemahan dari Bugerlijk Wetboek, Prandya Paramita, Jakarta, 2006

Usman,Rachmadi Hukum Jaminan Keperdataan, Sinar Grafika, Jakarta, 2008 
Wirjono Prodjodikoro, Hukum Wesel, Cek dan Aksep di Indonesia, Bale Bandung, Bandung, 1998.

\section{Peraturan Perundang-undangan :}

Undang-Undang Republik Indonesia Nomor 7 Tahun 1992 Tentang Perbankan Lembaran Negara Republik Indonesia Tahun 1992 Nomor 31, Lembaran Negara Tahun 1992 Nomor 31. Tambahan Lembaran Negara Nomor 3472

Undang-Undang Republik Indonesia Nomor 10 Tahun 1998 Tentang Perubahan UndangUndang Nomor 7 Tahun 1992 Tentang Perbankan, Lembaran Negara Republik Indonesia Tahun 1998 Nomor 182. Tambahan Lembaran Negara Nomor 3790 